\title{
Apresentação: Religiões na América Latina: continuidades e rupturas
}

Presentation: Religions in Latin America: Continuities and ruptures

\author{
Amurabi Oliveira \\ Departamento de Sociologia e Ciência Política \\ Universidade Federal de Santa Catarina (UFSC), Brasil \\ ORCID ID: https://orcid.org/0000-0002-7856-1196 \\ E-mail: amurabi1986@gmail.com
}

A América Latina tem sido objeto de contínua reflexão por parte de distintos pesquisadores, envolvendo tanto os intelectuais "nativos" quanto estrangeiros que se especializaram em pesquisar sobre a realidade sociocultural dessa região, que é fortemente marcada pelo "encontro colonial" (Lander, 2005). Destaca-se a idiossincrasia de sua formação história, que envolveu elementos culturais tão distintos quanto o indígena, o europeu e o africano, como bem destacam as análises clássicas realizadas por autores como Fernando Ortiz (1881-1969) em Cuba, e Gilberto Freyre (1900-1987) no Brasil.

No bojo dessas reflexões, ganha destaque o debate específico sobre as religiões em América Latina, considerando tanto aquelas que surgiram nessa região, quanto aquelas que apesar de possuírem origens diversas foram incorporadas ao campo religioso latino-americano, ganhando amiúde feições singulares. Ao indicarmos no título do dossiê as religiões na América Latina, e não exclusivamente as religiões latino-americanas, compromete-se, apontamos para um debate que incorpora também as diásporas religiosas que encontraram na América Latina substrato para sua expansão e diversificação.

A proposta deste número especial para a Revista del Cesla, publicação da Universidade de Varsóvia, surgiu a partir de um grupo de trabalho "Religiões na América Latina", cujas atividades ocorreram em agosto de 2019 durante o intercongresso da International Union of Anthropological and Ethnological Sciences 
(IUAES), na cidade de Poznan, Polônia. A diversidade de temáticas e de abordagens, trazidas por pesquisadores de diversas partes do mundo nos fomentou o desejo de organizar uma publicação mais ampla, que pudesse estar acessível a pesquisadores e pesquisadoras da América Latina e de outras partes do globo.

Recebemos um número bastante expressivo de trabalhos, contado com a participação de pesquisadores da Argentina, Brasil, Finlândia, França, Polônia etc., o que demonstra a capilaridade do debate sobre religiões na América Latina. Também devemos destacar que nesse número encontramos trabalhos escritos em castelhano, inglês e em português, dando destaque à polifonia existente nesse debate.

Com relação às temáticas exploradas, no presente número encontramos trabalhos sobre religiões afro-brasileiras, pentecostalismo, catolicismo, além dos novos movimentos religiosos. Esses temas em parte refletem uma agenda de pesquisa bastante consolidada nos estudos sobre religiões na América Latina, principalmente sobre religiões afro-brasileiras e sobre pentecostalismo, mas também abrem espaço para novos espaços e temáticas emergentes nesse campo.

Convidamos a comunidade de pesquisadores e pesquisadoras para se debruçar sobre esse número, enxergando-o como uma tentativa coletiva de apreensão da dinâmica religiosa na América Latina, utilizando-se de uma aproximação desde as ciências sociais, especialmente a partir da antropologia, da história e da sociologia.

\section{REFERÊNCIA}

Lander, E. (Ed.). (2005). A colonialidade do saber: eurocentrismo e ciências sociais Perspectivas latino-americanas. CLACSO. 